\title{
Outsourcing in Turkish Hospitals: A Systematic Review
}

\author{
Yasemin AKBULUT ${ }^{1, *}, 2$, Gözde TEREKLII ve Türkan YILDIRIM ${ }^{1}$ \\ ${ }^{1}$ Ankara Üniversitesi, Săglık Bilimleri Fakültesi, Să̆lık Kurumları Yönetimi Anabilim Dalı, Ankara, Turkey \\ *e-mail: akbulut@health.ankara.edu.tr
}

\section{Türkiye'deki Hastanelerde Dış Kaynak Kullanımı: Sistematik Bir Analiz}

\begin{abstract}
Özet
Dış kaynak kullanımı devlet hastanelerinde temel bir strateji haline gelmekte ve son zamanlarda tanınırlığı artmaktadır. Türkiye'de bu trendi oluşturan itici güç, özel sektördeki baskıların ve rekabetin kamu sektörünü daha verimli kılacağı gerçeğine dayanarak Sağlık Bakanlığı tarafından başlatılmıştır. $\mathrm{Bu}$ çalışmanın amacı, sistematik analiz yoluyla Türkiye'deki hastanelerde dış kaynak kullanımı konusunda elde edilen farklı araștırma bulgularını karşılaştırmak, bütünleştirmek ve gelecekteki araştırmalara yönelik öneride bulunmaktır. Analizde 2005 ve 2011 yılları arasında yayınlanmış toplam 15 çalışma (8 tez, 7 makale) kapsama alınmıştır. Bu çalışmaların sonuçlarına göre, dış kaynak kullanımının maliyetleri azalttığı, verimliliği ve hizmetlerin kalitesini artırdığı bulunmuştur. Sadece bir çalışmada dış kaynak kullanımının hastane maliyetlerine etkisi hastane kayıtlarına dayalı olarak incelenmiştir. Başka bir çalışmada ise hastane çalışanlarının memnuniyet düzeyi düşük bulunmuştur. Sonuç olarak, Türkiye'deki kamu ve özel hastanelerde diş kaynaklardan yararlanılarak verilen hizmetlerin etkilerini belirleyen objektif kalite, verimlilik ve maliyet indikatörlerine dayalı ampirik araştırmalara gereksinim duyulduğu söylenebilir.
\end{abstract}

Anahtar Kelimeler: Sistematik analiz, dış kaynak kullanımı, hastane yönetimi.

\begin{abstract}
Outsourcing has become a basis strategy in the public hospitals and has recently grown considerably in popularity. The impetus for this trend was the initiated by the Ministry of Health in Turkey with the fact that private sector pressures and competition would make public sector more efficient. The aim of the study is to compare and integrate different research findings carried out on outsourcing services in the hospitals in Turkey through a systematic review and to make suggestions for future researches. A total of 15 studies ( 8 dissertations and 7 articles) published between the years 2005 and 2011 were identified for inclusion in the present review. According to the results of these studies, outsourcing have decreased the costs, increased the productivity and the quality of services. In only one study the effect of outsourcing services was examined based on the hospital cost records. In another study the satisfaction level of hospital staff was found low. According to the results, it can be stated that there is a need some empirical research that will determine the effect of outsourcing services based on the indicators of objective quality, productivity and costs, in public and private hospitals in Turkey.
\end{abstract}

Keywords: Systematic review, outsourcing, hospital management

\footnotetext{
2 Bu çalışmanın ilk versiyonu 13-15 Haziran 2012 tarihleri arasında düzenlenen "Annual Conference of European Health Management"'da poster bildiri olarak sunulmuştur.
} 


\section{Introduction}

Competitive pressures, rising income levels, technological developments and increasing expectations of people along with globalization led to use widely outsourcing by organizations to survive and maintain their continuity. So, the use of outsourcing has grown exponentially in recent years with predictions for continued growth (Foxx et al., 2009). Most organizations now outsource various internal functions or sub-functions to outside vendors (Eliot, 1998; Kremic et al., 2006). The primary reasons for outsourcing are that decision-makers have wanted to reduce costs and increase efficiency, focus on core competetive advantage (Young, 2005) by relocating limited resources to strengthen their core product or service (Hatch, 1997; Kocel, 2005), introduce workforce flexibility, improve management of industrial relations' problems, satisfy decision-makers' personal objectives and adhere the ideology of governments (Young, 2005). Kakabadse and Kakabadse (2000) states that there are three major categories of motivations for outsourcing: cost, strategy, and politics. The first two commonly drive outsourcing by private industry. Political agendas often drive outsourcing by public organizations.

Outsourcing leds to organizations use resources effectively and get them a possibility to concentrate on the jobs they knew very well (Hatch, 1997; Kocel, 2005). Schönteich (2004) also determines benefits of outsourcing as lower cost, higher quality, greater flexibility in the provision of servies and a more rapid response to changing service and customer needs.

\section{Outsourcing Process}

Decisions of using outsourcing must be made relative to two distinct issues: (1) what service to outsource and (2) what vendor to use. Although choices relative to the service itself must generally precede vendor selection, these two decisions must be made concurrently. The decision-making process of outsourcing is illustrated in Figure 1 (Foxx et al., 2009).

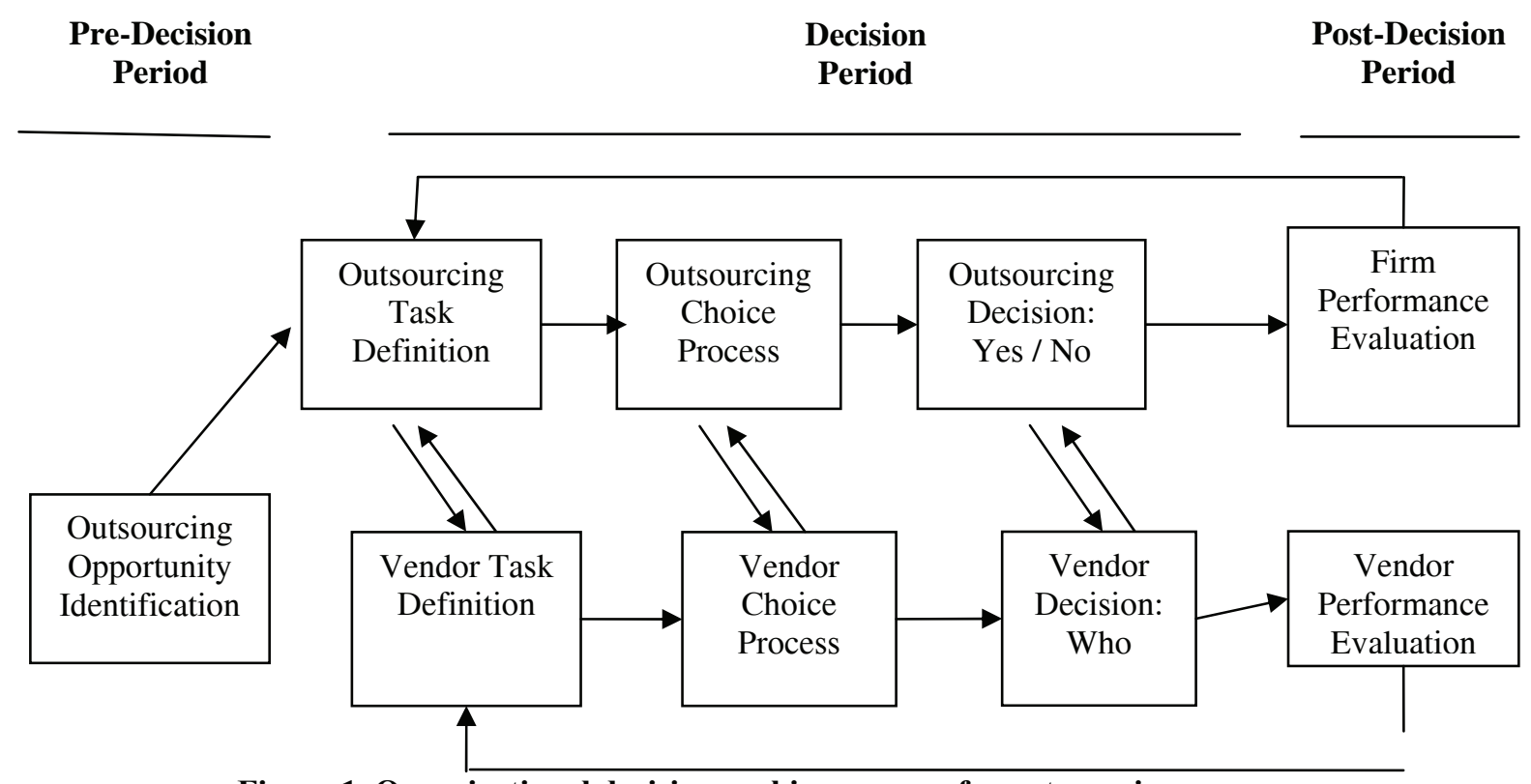

Figure 1. Organizational decision-making process for outsourcing

The process starts with the pre-decision stage on the left-hand side and moves sequentially to the right. During this period, the organization develops an awareness of service outsourcing and identifies areas in which it could benefit from its use. These potential benefits motivate efforts of the organization to seek further information relative to service outsourcing and to initiate a more through examination of their specific options. The organization next enters the decision period. At this point, 
the organization has neither committed to outsource nor to do so by contracting the service. Over the course of the decision period, the task to be outsourced is defined, the actual decision process is initiated, and a decision is made of whether to outsource or not. In the case of service outsourcing, these choices must be made with regard to both the task and vendor. Because outsourced services are more likely to be custom offerings and vendors have differing competences, decisions concerning the task and vendor typically cannot occur sequentially, but must occur in parallel. In fact, tasks under consideration often must be evaluated in light of whether any vendor is capable of providing the desired service. The outcomes of the decision period are choices regarding the service(s) to outsource, if any, and which vendor to select. During the post-decision period, evaluations of the outsourcing decision are made. If the decision to outsource a service was made and a vendor selected, performance will be evaluated relative to the vendor's service provision. Initially, an organization may choose to in source a task and surveys show organizations do in fact do so. Likewise, an organizationinitially deciding to in-source a task can choose to outsource it to a vendor at a later time. In either case, postpurchase evaluation will provide feedback for later decision-making (Foxx et al., 2009).

\section{Outsourcing in Hospitals}

At a time of rising competition and diminishing income possibilities, it is vitally important for hospitals to increase the economic performance (Kavuncubaşi and Yildirim, 2010). Since hospitals faced greater financial challenges, the healthcare establishment encountered a competitive environment requiring greater quality of care, patient volume and access to scarce resources. So, one way in which healthcare organizations responded to these changes is through the use of outsourcing (Foxx et al., 2009).

Because of the unique aspects of healthcare, however, this sector was at first slow to use outsourcing. There is now great interest and the nature and type of services being outsourced by health organizations has expanded. In fact, the healthcare sector is one of the fastest growing areas for outsourcing. At the same time, the number of vendors competing for outsourcing contracts has increased dramatically and competition has intensified (Foxx et al., 2009).

Functions that are outsourced in the health field are such as specialized medical departments in hospitals, support services for hospital, clinical services, and business services (Burkholder, 2006). For decades, hospitals have been used outsourcing activities such as housekeeping, food service, laundry, accounts receivable, clinical/diagnostic equipment maintenance, foreign language services, emergency departments, anesthesia, hospital call centers, cardiology, pharmacy, security, information systems, facility operations, parking garages, rehabilitation, psychiatric facility grounds and medical records all over the world (Miller and Washington, 2007).

A key motivation for interest in outsourcing is the intense competitive pressure healthcare institutions face with respect to improving quality and productivity, although containing cost at the same time (Foxx et al., 2009). Kavuncubasi and Yildirim (2010) states that the main purpose of outsourcing practices in the health field is to increase efficiency and quality of services by providing to focus on the basic processes and patients. A research on outsourcing practices also shows that outsourcing had a positive effect on accessing to health care and efficiency, equality and quality of health services provision.

Hospitals, a public sector enterprise in Turkey, in recent years have transformed into the organizations composed of high technology, specialized personnel and complicated production processes. With a matrixical organizational scheme, hospitals are comprised of a number of professional groups that involve many employees of diverse education background, skills, values, needs, social statuses, and production processes that are functionally interrelated (Mollahaliloglu et al., 2010).

In the post-1980 period, the phenomenon of outsourcing also became an increasingly common practice in Turkey (Mollahaliloglu et al., 2010). So in Turkey, almost all hospitals provide at least a 
service via outsourcing (Kavuncubasi and Yildirim, 2010). Service procurement was used in the health care sector primarily for laundry, cleaning and catering services, which are called "hotel business services" in Turkey because of easy to manage and supervise initially. However, in conjunction with the reforms implemented under the Health Transformation Program, the scope of outsourcing has expanded to provide advanced and specialized medical services such as Magnetic Resonance and Computerized Tomography, and to managerial activities such as billing and data registration with the aim of adapting to the evolving business environmental, technologic, and economic changes. The health sector, in general, and hospitals in particular, may prefer to provide business processes from another organization that specializes in that process for the purpose of upgrading institutional performance when they wish to improve the outcomes of a certain item of service with regards to quality, efficiency and effectiveness (Mollahaliloglu et al., 2010).

In light of such a conceptual background, this study aims to compare and integrate of different research findings carried out on outsourcing services in the hospitals in Turkey through a systematic review and to make suggestion for future researches.

\section{Method}

Systematic reviews are secondary research projects that compile all the randomized trials addressing a particular question of interest. The processes and the procedures used to identify and select studies, extract and synthesize data must be standardized, transparent, and reproducible for a review to be classed as systematic (Ata ve Urman, 2008).

\section{Data Sources}

A two-step process was used to identify studies for inclusion in this review. First, candidate studies were located using the Institutions of Higher Education Database in Turkey for dissertations, Ebscohost, Elsevier Science Direct, Annual Reviews, Cambridge University Press, Elsevier Scopus, Oxford University Press, Springer Link, ISI-Web of Science, PubMed and Medline databases. Searches were conducted using the all years inclusive. In other words, studies had to be searched without a range of years. A set of keywords was developed to use in the initial search. The keywords for each retrieved study were reviewed to identify alternative identifiers that were cataloged and used in subsequent searches. The keywords included "outsourcing, outsourcing in hospital, using outside sourcing and outsourcing in Turkey". Second, after searching, the inclusion criteria were used for selecting studies.

\section{Inclusion Criteria}

Inclusion criteria typically belong to one or more of the categories such as study population, nature of the intervention, outcome variables, time period, cultural and linguistic range, and methodological quality (Meline, 2006). To help synthesize the findings, the following five criteria were used in our study to determine if a particular study was eligible for inclusion. First, they had to be conducted only in related to outsourcing. Second, investigating studies had to be performed only in public or private hospitals located in Turkey. Third, they had to be assessed to full text. Fourth, they had to be published in Turkish and English and last they had to be published as only national or international research articles or dissertations not as a book.

\section{Study Selection}

After having limited search results for studies published in Turkish and English, a total of 24 different studies were identified until January 2012. In terms of study screening, all of potentially eligible studies were screened by two independent reviewers. Each of the canditate studies was categorized either being eligible or ineligible for further review. The first round consisted of critically reading the title, keywords and abstract. In the second round both reviewers independently assessed the full text of the articles selected in the first round. Each of these studies used single-subject methods to examine the impact of outsourcing on hospital efficiency, quality and cost containment. A 
schematic representation of the searcing prosess with an explanation of why some studies eliminated is located in Figure 2.

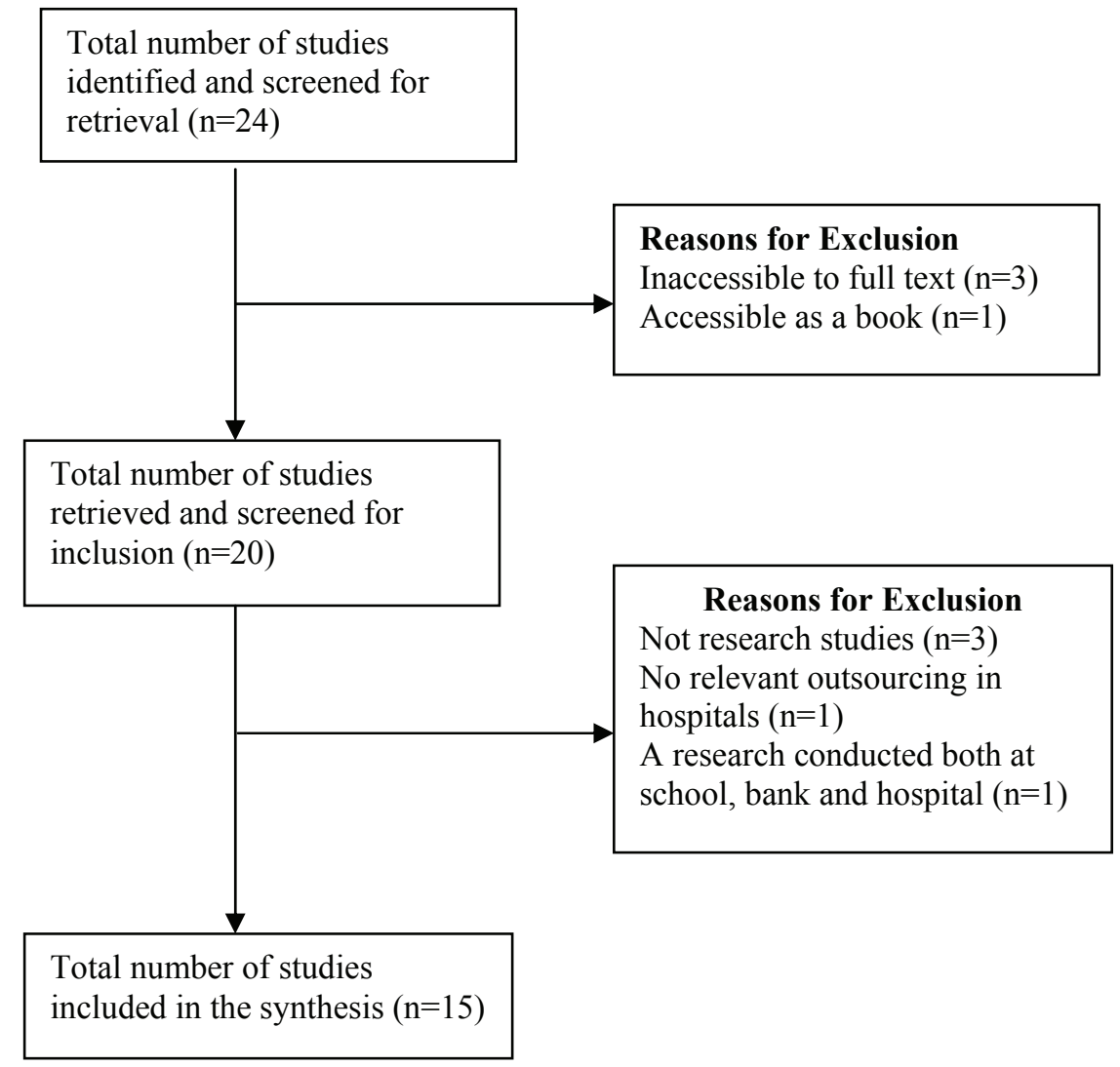

\section{Results}

Figure 2. Flow chart of study selection for the systematic review

Although searches were conducted using the all years inclusive, a total of 15 studies ( 8 dissertations, 7 articles) published between the years 2005 and 2011 were included in the review. Table 1 lists the characteristics of included studies. 
Table 1. Characteristics of studies included in the review

\begin{tabular}{|c|c|c|c|c|c|}
\hline Number & Author & Name & Date & Type & Language \\
\hline SN 1 & Karahan A. & $\begin{array}{l}\text { Impact of Outsourcing on Productivity } \\
\text { (Research on Hospital Managers) }\end{array}$ & 2009 & Article & Turkish \\
\hline SN 2 & Ergin G. and Sahin I. & $\begin{array}{l}\text { Service Procurement as a Tool } \\
\text { Outsourcing: A Study on Evaluations by } \\
\text { Hospital Administrators of Ministry of } \\
\text { Health in Turkey }\end{array}$ & 2005 & Article & Turkish \\
\hline SN 3 & Ecerkale K. & Outsourcing in the Health Care Sector & 2006 & Article & Turkish \\
\hline SN 4 & $\begin{array}{l}\text { Mollahaliloglu S., } \\
\text { Kavuncubasi S., Gursoz } \\
\text { H., Agirbas I, Ari H.O., } \\
\text { Oncul H.G., Akdağ R. } \\
\text { and Younis M.Z } \\
\end{array}$ & $\begin{array}{l}\text { Outsourcing Profile in the Turkish } \\
\text { Health Care System }\end{array}$ & 2009 & Article & English \\
\hline SN 5 & $\begin{array}{l}\text { Yalcin I., Akin M. And } \\
\text { Seker M. }\end{array}$ & $\begin{array}{l}\text { Outsourcing in Public Hospitals: The } \\
\text { Case of Kayseri Training and Research } \\
\text { Hospital }\end{array}$ & 2011 & Article & Turkish \\
\hline SN 6 & Cakıcı A.B. & $\begin{array}{l}\text { Modern Management Strategies and } \\
\text { Outsourcing: The Case of An Health } \\
\text { Organization }\end{array}$ & 2006 & Dissertation & Turkish \\
\hline SN 7 & Arslanoglu A. & $\begin{array}{l}\text { Outsourcing in Management and A } \\
\text { Research in the Health Sector }\end{array}$ & 2009 & Dissertation & Turkish \\
\hline SN 8 & Yagmur A. & $\begin{array}{l}\text { Outsourcing as a Tool and Method } \\
\text { Benefiting from Core Competencies } \\
\text { More Effectively: A Theory and } \\
\text { Comparative Research in Health } \\
\text { Organizations }\end{array}$ & 2007 & Dissertation & Turkish \\
\hline SN 9 & Karaca A. & $\begin{array}{l}\text { Outsourcing in Marketing of Health } \\
\text { Services and An Application for the Use } \\
\text { of Outsourcing in Health Care } \\
\text { Organizations }\end{array}$ & 2006 & Dissertation & Turkish \\
\hline SN 10 & Yilmaz G. & $\begin{array}{l}\text { Outsourcing at Hospital Services in } \\
\text { Turkey and Evaluation of Managers }\end{array}$ & 2007 & Dissertation & Turkish \\
\hline SN 11 & Meral Y. & $\begin{array}{l}\text { A Research on the Impact of } \\
\text { Outsourcing on Patient Satisfaction in } \\
\text { Health Care }\end{array}$ & 2006 & Dissertation & Turkish \\
\hline SN 12 & Sagnak P. & $\begin{array}{l}\text { The Role of Outsourcing on Creating } \\
\text { Service Quality and Customer } \\
\text { Satisfaction at Hospitals and Use of } \\
\text { Outsourcing As a Marketing Tool: A } \\
\text { Research in the Hospital of Gülhane } \\
\text { Military Medical Faculty }\end{array}$ & 2010 & Dissertation & Turkish \\
\hline SN 13 & Ozdemir M. & $\begin{array}{l}\text { Outsourcing for the Security Services } \\
\text { and A Study in the Public Hospitals in } \\
\text { the Region of Black Sea }\end{array}$ & 2010 & Dissertation & Turkish \\
\hline SN 14 & Ozgener S. and Kucuk F. & $\begin{array}{l}\text { The Effect of Modern Management } \\
\text { Philosophy on Productivity in Hospitals: } \\
\text { A Practice in Gevher Nesibe Hospital }\end{array}$ & 2008 & Article & Turkish \\
\hline SN 15 & $\begin{array}{l}\text { Yigit V., Tengilimoglu } \\
\text { D., Kisa A. And Younis } \\
\text { M.Z. }\end{array}$ & $\begin{array}{l}\text { "Outsourcing and Its Implications for } \\
\text { Hospital Organizations in Turkey" }\end{array}$ & 2007 & Article & English \\
\hline
\end{tabular}


It was found that all the clinics and non-clinic departments of the hospitals surveyed used outsourcing services. Especially, there is an increased use of outsourcing in public hospitals.

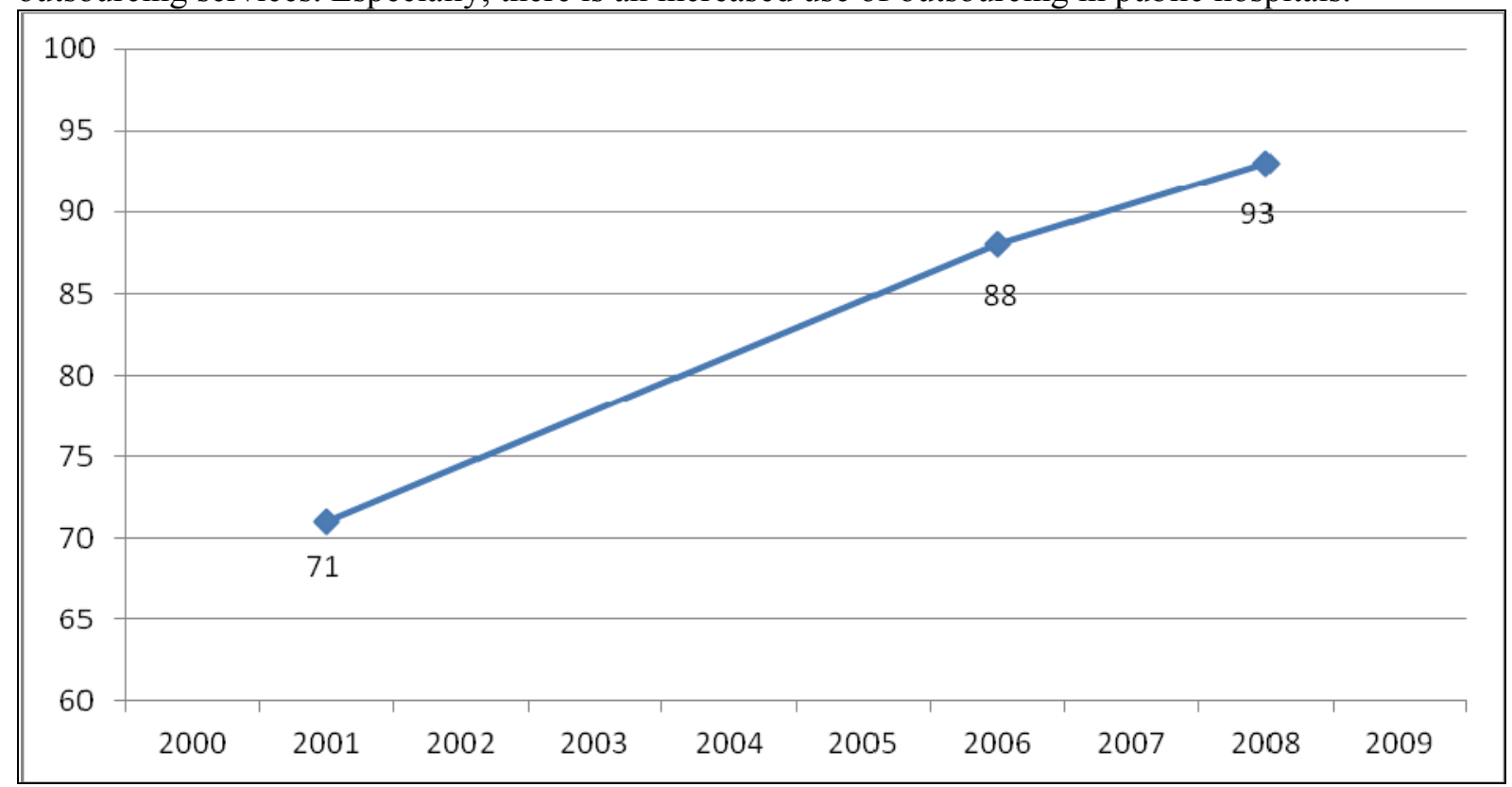

Figure 3. Ratio of the hospitals using outsourcing services in Turkey (2001-2008)

Figure 3 highlights the number of hospitals which provide one service at least using outsourcing increased $22.5 \%$ between 2001 and 2008. The share of hospitals using outsourcing was $71 \%$ in 2001 . It has been seen by 2008 that $93 \%$ of public hospitals in Turkey used outsourcing at least for one service (Engin and Şahin, 2001, Mollahaliloğlu et al., 2010, Y1lmaz, 2006).

Table 2. Some information on the studies included in the review

\begin{tabular}{|l|c|c|l|l|l|l|l|l|}
\hline Study Groups & $\mathbf{n}$ & $\mathbf{\%}$ & Hospital Type & $\mathbf{n}$ & $\mathbf{\%}$ & Sample Size & $\mathbf{n}$ & $\mathbf{\%}$ \\
\hline Hospital Administrators & 7 & 46.7 & Public Hospitals & 9 & 60 & Country Level & 1 & 6.6 \\
\hline Patients & 3 & 20 & & & & & & \\
\hline Hospital Staff & 4 & 26.6 & $\begin{array}{l}\text { Public and } \\
\text { Private } \\
\text { Hospitals }\end{array}$ & 6 & 40 & Hospital Level & 14 & 43. \\
\hline $\begin{array}{l}\text { Cost of the Hospital } \\
\text { Records }\end{array}$ & 1 & 6.7 & & & & & & \\
\hline
\end{tabular}

Some of the research $(60 \%)$ was carried out in public hospitals and $40 \%$ in both public and private hospitals. Many researches were carried out in hospitals in different provinces and only $6.6 \%$ conducted inacross the country. The studies were carried out on hospital administrators $(46.7 \%)$, patients $(20 \%)$, hospital staff $(26.6 \%)$ and the cost of the hospital records $(6.7 \%)$.

Some studies $(73.3 \%)$ were carried out to determine reasons for using outsourcing in some services and areas in which outsourcing used and $26.6 \%$ of the studies were executed to determine the satisfaction level of outsourcing users. In the studies conducted to determine the satisfaction level of outsourcing services users in the hospitals $(n=4)$, the satisfaction level of patients was found above average $(n=2)$, hospital staff were found below average $(n=1)$, and managers' satisfaction were as high level $(n=1)$. Some studies $(38.8 \%)$ indicate that outsourcing has improved the quality ofservices, $3.3 \%$ decreased the cost of services, $27.7 \%$ increased the productivity and efficiency. 


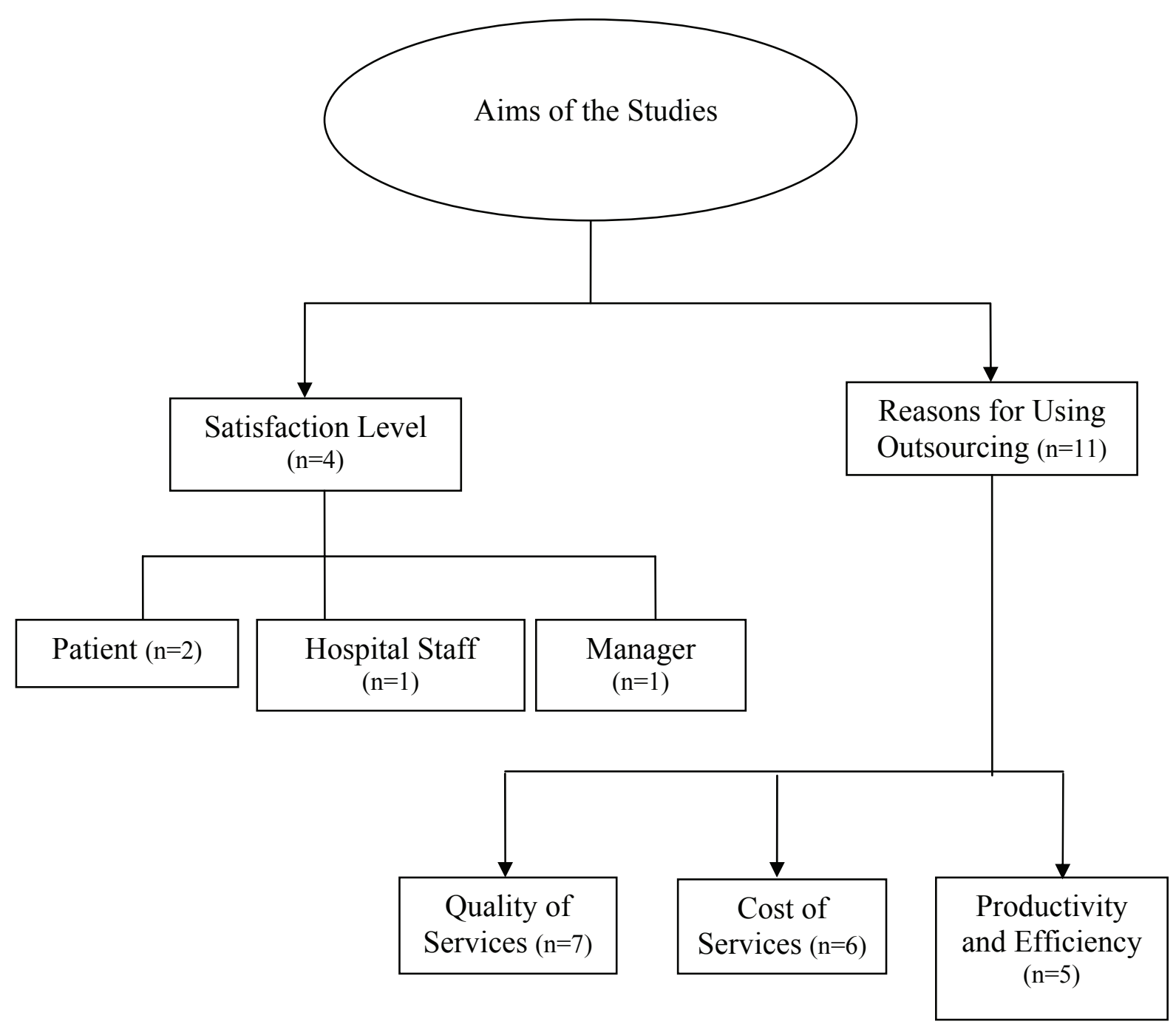

Figure 4. Aims of the Studies

\section{Conclusion}

Outsourcing is an important managerial issue for the health care sector. This study examines different research findings carried out on outsourcing services in the hospitals in Turkey through a systematic review. Our systematic literature search was designed to give better complete overview of the studies on outsourcing services in the hospitals and to make suggestions for future researches. Systematic liteature review results for this study indicate that most of the studies $(n=14)$ examined knowledge and opinions of hospital staff, managers and patients about outsourcing. According to the results of these studies, the outsourcing services have decreased the costs, increased the productivity and quality of services. In only one study the effect of outsourcing services on the hospital cost was examined. In another study the satisfaction level of hospital staff was found as low. In light of this information future research might examine underlying causes of positive and negative outsourcing effects on hospital performance. In additiion the effects of outsourcing need to be examined in detail on the indicators of objective quality, productivity and costs, especially risk analysis research, in public and private hospitals in Turkey. 


\section{References}

Ata, B., Urman, B. 2008. Critical appraisal of systematic reviews. Journal of Turkish Society of Obstetric and Gynecology, Vol: 5 Issue: 4 Pages: 233- 240 (in Turkish)

Burkholder, N.C. 2006. Outsourcing: the definitive view, applications and implications. John Wiley \& Suns, Inc.

Dorthch, W.L. \& Davis, L.L.P. 2006. Sponsored material special supplement to health leaders http://www.wallerlaw.com.sitemason.com/files/WallerSurvey.pdf.

Eliot, L.B. 1998. Outsourcing of organizational functions. Decision Line, A News Publication of the Decision Sciences Institute, Volume 29 (4).

Ergin, S. \& Sahin, I. 2001. Contracting out as intermediary outsourcing: a study of the ministry of health of Turkey hospital managers' evaluation. Hacettepe Journal of Health Administration.

Foxx, W.K., Bunn, M.D. \& Mccay, V. 2009. Outsourcing services in the healthcare sector. Journal of Medical Marketing, Vol: 9 Issue: 1 Pages: 41-55.

Hatch, M.Jo. 1997. Organization theory: Modern symbolic and postmodern perspectives. Oxford University Press.

Kakabadse, A. \& Kakabadse, N. 2000. Sourcing: New face to economies of scale and the emergence of new organizational forms. Knowledge and Process Management, Vol: 7 Issue: 2, Pages 107-18.

Kavuncubasi, S. \& Yildirim, S. 2010. Hastane ve sağllk kurumları yönetimi. Gözden Geçirilmiş ve Genişletilmiş 2. Bask1, Siyasal Kitabevi, Ankara.

Koçel, T. 2005. İşletme Yönetimi. 10. Basım. Arıkan Basım Yayın Dağıtım Ltd. Şti. Istanbul.

Kremic, T., Icmeli, O. \& Rom Walter, O. 2006. Outsourcing decision support: A survey of benefits, risks, and decision factors. Supply Chain Management: An International Journal, Vol: 11 Issue: 6 Pages: 467-482.

Meline, T. 2006. Selecting studies for systematic review: Inclusion and exclusion criteria. Contemporary Issues in Communication Science and Disorders, Volume 33, 21-27 Spring 2006, NSSLHA.

Miller, R.K. \& Washington, K.D. 2007. The 2006 Healthcare business market research handbook, Pages: 124-127.

Mollahaliloglu, S., Gursoz, H., Ari, H.O. \& Oncul, H.G. 2010. Türk Sağl1k Sistemi'nde Kurum Dışından Hizmet Alımı Uygulamaları, Araştırma Serisi 1, Ankara, Sağlık Bakanlığı, Pages: 19.

Mollahaliloglu, S., Kavuncubasi, I., Gursoz, H., Agirbas, I., Ari, H.O., Oncul, H.G., Akdağ, R., \& Younis, M.Z 2009. Outsourcing profile in the Turkish health care system, Journal of Health Care Finance, Vol: 35 Issue: 4 Pages: 74-82

Schonteich, M. 2004. Outsourcing: Risks and Benefits (Chapter 2), In (eds M. Schonteich, A. Minnaar, D. Mistry, \& K.C Goyer) Private Muscle: Outsourcing, Monograph No. 93. Pretoria: Institute for Security Studies.

Yilmaz, G. 2007. Outsourcing in Hospital Services in Turkey and its Evaluation from the Perspectives of the Managers Who Acquire These Services. Unpublished Ph.D Dessertation. Trabzon Karadeniz Technical University.

Young, S. 2005. Why outsource and what makes it work? Alternative arrangements for work in the health sector" in Reworking Work AIRAAN, proceedings of 19th Conferance The Association of Industrial Relations Academics of Australia and New Zealand, Volume 1 refereed papers, pp: 573581. http://airaanz.econ.usyd.edu.au/papers/Young.pdf. 